prescriptions for selected antibiotics has been followed by significant reductions in their use. ${ }^{12,13}$ Computer alerts generated at the time of drug prescription also show promise in addressing the complex problem of antimicrobial misuse. ${ }^{14,15}$

A range of healthcare-system-based options to reduce inappropriate use has been proposed, ${ }^{16-18}$ but, to be effective, any restrictions ultimately will have to be accepted by those laboring under them. Each hospital will need to adopt strategies that are most likely to be workable, given the hospital's resources, the personalities of its staff, and its philosophy. ${ }^{19}$

Before publication of the HICPAC guidelines, vancomycin use had risen substantially; one university hospital documented a 20 -fold increase from 1981 through 1991.10 Recent isolations of $S$ aureus with decreased susceptibility to vancomycin underscore the problem of the intense selective pressure applied by this use. ${ }^{20,21}$ We would ask physicians to accept as reasonable and in the best interest of patients the trade-off of limits on their prerogative to prescribe certain antibiotics in exchange for a friendlier hospital microbial milieu.

\section{REFERENCES}

1. Centers for Disease Control and Prevention. Nosocomial enterococci resistant to vancomycin-United States, 1989-1993. MMWR 1993;42: $597-599$.

2. Spera RV Jr, Farber BF. Multidrug-resistant Enterococcus faecium-an untreatable nosocomial pathogen. Drugs 1994;48:678-688.

3. Noble WC, Virani Z, Cree RGA. Co-transfer of vancomycin and other resistance genes from Enterococcus faecalis NCTC 12201 to Staphylococcus aureus. FEMS Microbiol Lett 1992:93:195-198.

4. Centers for Disease Control and Prevention. Recommendations for preventing the spread of vancomycin resistance. Recommendations of the Hospital Infection Control Practices Advisory Committee (HICPAC). MMWR 1995;44(RR-12):1-13.

5. Evans ME, Kortas KJ. Vancomycin use in a university medical center: comparison with Hospital Infection Control Practices Advisory Committee guidelines. Infect Control Hosp Epidemiol 1996;17:356-359.
6. Beidas $\mathrm{S}$, Khamesian $\mathrm{M}$. Vancomycin use in a university medical center: comparison with Hospital Infection Control Practices Advisory Committee guidelines. Infect Control Hosp Epidemiol 1996;17:773774.

7. Johnson SV, Hoey LL, Vancy-Bryan K. Inappropriate vancomycin prescribing based on criteria from the Centers for Disease Control and Prevention. Pharmacotherapy 1995;15:579-585.

8. Morgan AS, Brennan PJ, Fishman NO. Impact of a vancomycin restriction policy on use and cost of vancomycin and incidence of vancomycinresistant Enterococcus. Ann Pharmacother 1997;31:970-973.

9. Logsdon BA, Lee KR, Luedtke G, Barrett FF. Evaluation of vancomycin in a pediatric teaching hospital based on CDC criteria. Infect Control Hosp Epidemiol 1997;18:780-782.

10. Ena J, Dick RW, Jones RN, Wenzel RP. The epidemiology of intravenous vancomycin usage in a university hospital. JAMA 1993;269:598-602.

11. Woodward RS, Medoff G, Smith MD, Gray JL. Antimicrobial cost savings from formulary restrictions and physician monitoring in a medicalschool-affiliated hospital. Am J Med 1987;83:817-823.

12. McGowan JE Jr, Finland M. Usage of antibiotics in a general hospital: effect of requiring justification. I Infect Dis 1974;130:165-168.

13. Anglim AM, Klym B, Byers KE, Scheld WM, Farr BM. Effect of a vancomycin restriction policy on ordering practices during an outbreak of vancomycin-resistant Enterococcus faecium. Arch Intern Med 1997;157:1132-1136.

14. Pestotnik SL, Classen DC, Evans RS, Burke JP. Implementing antibiotic practice guidelines through computer-assisted decision support: clinical and financial outcomes. Ann Intern Med 1996;124:884-890.

15. Singer MV, Haft R, Barlam T, Aronson M, Shafer A, Sands KE. Vancomycin control measures at a tertiary-care hospital: impact of interventions on volume and patterns of use. Infect Control Hosp Epidemiol 1998;19:248-253.

16. Jarvis WR. Preventing the emergence of multidrug-resistant microorganisms through antimicrobial use controls: the complexity of the problem. Infect Control Hosp Epidemiol 1996;17:490-495.

17. Duncan RA. Controlling use of antimicrobial agents. Infect Control Hosp Epidemiol 1997;18:260-266.

18. John JF Jr, Fishman NO. Programmatic role of the infectious diseases physician in controlling antimicrobial costs in the hospital. Clin Infect Dis 1997;24:471-485.

19. Goldmann DA, Weinstein RA, Wenzel RP, Tablan OC, Duma RJ, Gaynes $\mathrm{RP}$, et al. Strategies to prevent and control the emergence and spread of antimicrobial-resistant microorganisms in hospitals: a challenge to hospital leadership. JAMA 1996;275:234-240.

20. Centers for Disease Control and Prevention. Reduced susceptibility of Staphylococcus aureus to vancomycin-Japan, 1996. MMWR 1997;46: 624-626.

21. Centers for Disease Control and Prevention. Staphylococcus aureus with reduced susceptibility to vancomycin-US. MMWR 1997;46:765-766.

\title{
Surgical Patients With Clostridium difficile-Associated Diarrhea
}

\section{Gina Pugliese, RN, MS Martin S. Favero, $\mathbf{P h D}$}

Crabtree and coinvestigators from the University of Virginia Department of Surgery prospectively studied all episodes of treated Clostridium difficile-associated diarrhea $(\mathrm{CDAD})$ in surgical inpatients at the University of Virginia Hospital from December 1996 through March 1998. CDAD accounted for $3.2 \%$ (32) of 1,000 total infections. Compared with a randomly selected control group with other nosocomial infections, patients with CDAD had a longer period from the time of admis- sion to diagnosis of infection $(19 \pm 4$ vs $9 \pm 1 ; P=.01$ ), were more likely to be female $(66 \%$ vs $37 \% ; P=.009)$, and had a higher overall crude mortality $(31 \%$ vs $11 \% ; P=.01$ ), although there were no deaths directly attributable to CDAD. Ciprofloxacin (19\%) and cefoxitin (16\%) were the most common individual antibiotics prescribed before the diagnosis of CDAD. The average time from completion of antibiotic therapy to diagnosis of CDAD was $7 \pm 2$ days (range, $0-58$ ). Sixteen percent $(5 / 32)$ developed CDAD after administration of prophylactic perioperative antibiotics only. The authors concluded that the high crude mortality rate associated with
CDAD suggests that this may be an important predictor of poor outcome among infected surgical patients. Antibiotics used commonly but not classically associated with CDAD frequently precipitate this infection. In addition, the use of prophylactic antibiotics is not without risk, as demonstrated by the substantial percentage of $\mathrm{CDAD}$ occurring after routine administration of these agents.

FROM: Crabtree TD, Pelletier SJ, Gleason TG, Pruett TL, Sawyer RG. Clinical characteristics and antibiotic utilization in surgical patients with Clostridium difficileassociated diarrhea. Am Surg 1999; 65:507-511. 